\title{
A View of Personality Disorder from the Colonial Periphery
}

\author{
FW Hickling ${ }^{1}$, G Walcott ${ }^{2}, 3$
}

\begin{abstract}
Objective: To examine the history of personality disorder in the context of contemporary post-colonial Jamaican society.

Methods: The literature outlining the development and classification of personality disorder is reviewed. The social, psychiatric and epidemiological studies of personality disorder in Jamaica are presented.

Results: A categorical classification system of personality disorder has been in use by the International Classification of Diseases (ICD) and the Diagnostic and Statistical Manual of Mental Disorders (DSM) from the mid 20 th century. Challenging that approach is the Minnesota Multiphasic Personality Inventory (MMPI), which represents the dimensional method, which views pathology as a continuum from normal personality traits. Both systems suffer from an absence of cultural flexibility, an absence of a system of severity, and a lack of treatment specificity, which foster misdiagnosis while making treatment planning difficult and unreliable. The proposed DSM-5 attempts to integrate a prototypematching system and identification of personality traits promises disappointing outcomes. The University of the West Indies, Section of Psychiatry, proposes a phenomenological nosological approach, advocating an alternate DSM Axis I category called Shakatani derived from Swahili shaka (problem), tani (power), and developing a 38-item Jamaica Personality Disorder Inventory (JPDI) screening questionnaire for diagnosing this condition. The epidemiological results using this instrument are reviewed, and the Jamaican print, broadcast and social media responses to this research in Jamaica are described.

Conclusions: The heritage of slavery and colonial oppression in Jamaica has resulted in maladaptive personality disorders that have led to extremely high rates of homicide, violence and transgressive behaviour.
\end{abstract}

Keywords: Homicide, personality disorder, post-colonial Jamaica, Shakatani, transgressive behaviour

\section{Una Perspectiva de los Trastornos de Personalidad desde la Periferia Colonial}

\author{
FW Hickling ${ }^{1}$, G Walcott ${ }^{2}, 3$
}

\begin{abstract}
RESUMEN
Objetivo: Examinar la historia de los trastornos de la personalidad en el contexto de la sociedad jamaicana postcolonial contemporánea.

Métodos: Se examina la literatura que bosqueja el desarrollo y la clasificación de los trastornos de la personalidad. Se presentan estudios sociales, psiquiátricos y epidemiológicos de los trastornos de personalidad en Jamaica.
\end{abstract}

\footnotetext{
From: ${ }^{1}$ Caribbean Institute of Mental Health and Substance Abuse (CARIMENSA), Faculty of Medical Sciences, The University of the West Indies, Kingston 7, Jamaica, ${ }^{2}$ Department of Community Health and Psychiatry, The University of the West Indies, Kingston 7, Jamaica and ${ }^{3}$ South East Regional Health Authority, Kingston and St Andrew Public Health Service, 1 Marescaux Road, Kingston 5, Jamaica.
}

Correspondence: Professor FW Hickling, Caribbean Institute of Mental Health and Substance Abuse (CARIMENSA), Faculty of Medical Sciences, The University of the West Indies, Kingston 7, Jamaica. E-mail: frederick.hickling@uwimona.edu.jm; fred@fredhickling.com 
Resultados: Un sistema de clasificación por categorías de los trastornos de la personalidad ha formado parte de la Clasificación Internacional de Enfermedades (CIE) y el Diagnóstico y Manual Estadístico de los Trastornos Mentales (DSM) desde mediados del siglo 20. Un reto a tal enfoque, lo hallamos en el Inventario Multifásico de Personalidad de Minnesota (MMPI, por sus siglas en inglés: Minnesota Multiphasic Personality Inventory). El MMPI representa un método dimensional, que considera la patología como un continuo que parte de rasgos de la personalidad normal. Ambos sistemas sufren de falta de flexibilidad cultural, ausencia de un sistema de severidad, y falta de especificidad con respecto al tratamiento. Tales faltas promueven un diagnóstico erróneo, a la par que hacen que la planificación del tratamiento sea dificil y poco confiable. El DSM-5 que se propone, constituye un intento por integrar un sistema de pareamiento de prototipos, y la identificación de rasgos de personalidad augura resultados decepcionantes. El Departamento de Psiquiatría de la Universidad de West Indies propone un enfoque fenomenológico nosológico, que aboga por una categoría alternativa del Eje I del DSM, denominada Shakatani, derivada del Swahili shaka (problema), tani (poder), y el desarrollo de un Inventario de Trastornos de la Personalidad en Jamaica (JPDI), consistente en un cuestionario de tamizaje de 38 items destinados a diagnosticar esta condición. Se revisan los resultados epidemiológicos que utilizan este instrumento, y se describen las respuestas dadas a esta investigación por los medios sociales, la televisión, la radio y la prensa escrita de Jamaica,

Conclusiones: La herencia de la esclavitud y la opresión colonial en Jamaica ha traído como resultado trastornos de personalidad por inadaptación, los cuales a su vez han llevado a tasas extremadamente altas de homicidios, violencia y conducta transgresora.

Palabras claves: Homicidio, trastornos de personalidad, Jamaica postcolonial, shakatani, comportamiento transgresor

West Indian Med J 2013; 62 (5): 384

\section{INTRODUCTION}

Jamaican Prime Minister Michael Manley (1) articulated the profound nature of the United States of America's (USA) involvement in the affairs, history and problems of Jamaica, South America and the Caribbean. The first Governor of the island, Sir Henry Morgan, an Admiral of the British navy, made his name as a successful and ruthless undisputed king of the buccaneers in the colonial Caribbean. Morgan established his reputation as a fierce 'privateer' of the English Government, making his living by overt and blatant theft, murderous invasion and capture, genocidal enslavement, oppression and extortion. To the psychiatrist of the $21^{\text {st }}$ century, Morgan would certainly fit at least six of the ten requirements for a Diagnostic and Statistical Manual of Mental Disorders, $4^{\text {th }}$ edition, text revision (DSM-IV-TR) diagnosis of 'antisocial personality disorder' (2). Europe and the USA have been significant architects of the contemporary social, economic and psychological fabric of colonies like Jamaica. The objective of this review is to examine the history of the concept of personality disorder in psychiatry and to chronicle the colonial developmental origins of this psychopathology in contemporary post-colonial Jamaica.

\section{The classification of personality disorder}

The classification of personality disorder dates as far back as 150-200 AD to the work of Hippocrates and Galen $(3,4)$. In the nineteenth century, individuals whose behaviours were socially disruptive were not categorized as insane (5-7). Their pathology was identified with psychological stressors and indicative of character flaws. Pritchard (7) coined the term 'moral insanity' as an abnormality equivalent to mental illness. Koch (8) first introduced the term "psychopathic" in 1891 to describe individuals with personality disorder but this term did not achieve widespread recognition until reformulated by Schneider (9). Henderson's (10) descriptions of psychopathic states had a major influence on the American and British conceptualization of personality disorder. However, he included only the most severe forms of behavioural abnormality as aggressive, inadequate and creative but ignored all patients with mild symptoms who suffered from internal distress but had no societal impact.

The International Classification of Diseases (ICD) formulated by the World Health Organization (11) and Diagnostic and Statistical Manual of Mental Disorders (DSM) created by the American Psychiatric Association (APA) in 1968 (2) have used the categorical classification system with a constellation of characterological descriptions similar to those of Schneider. That approach has been challenged by the dimensional approach, which views pathology as a continuum from normal personality traits, and which originated from personality traits. The Minnesota Multiphasic Personality Inventory (MMPI) has been the most widely used dimensional model, with 450 identified personality traits (12). Traits are not directly observable but rather govern the pattern of behavioural responses and therefore are not pathological (3).

The DSM personality disorder classification has had seven iterations in its evolution since it first appeared as 
DSM-I in 1952. Eleven categories of personality disorder appeared in the DSM-II in 1968 and were reformulated in DSM-III. An attempt was made to redress the clinical utility of the eleven-category system by the development of the cluster model in DSM-IV in 1994 (13) that appeared in DSM-IV-R as Cluster A (Odd/Eccentric), Cluster B (Dramatic/Emotional) and Cluster C (Anxious/Fearful). With the appearance of DSM-III-R in 1987, all categories remained the same in the subsequent editions of the DSM and were incorporated into the Cluster A, B and C categorizations.

\section{Critical considerations}

Developments of the classification systems (DSM/ICD) of personality disorder have been inordinately influenced by European and American conceptualizations. The APA DSM classification is the gold standard for many countries, and defines personality disorder as "... an enduring pattern of inner experiences and behaviours that deviates markedly from the expectations of the culture of the individual that exhibits it..." This "one size fits all" diagnostic categorization raises profoundly troubling questions about the homogeneity of cultural expectations within multicultural ethnic and different racial settings. Personality constructs were found to vary significantly when comparing ethnicity and socio-economic status within black Americans, white Americans and black Jamaicans (14). Significant differences were elicited in the personality between the white cohort and the black cohorts, and between those from the Caribbean and the USA.

In the ICD and the DSM personality disorders, disorder is diagnosed when a threshold amount of categorical indicators is present, with persons who fall short of this threshold being excluded. However, patients who had a sub-threshold number of symptoms have been found to be more clinically similar to those who had a diagnosis than those who did not (15). These categorical systems do not adequately describe the breadth of psychological dysfunction that occurs in individual behaviour, with the full range of meaning and function of these dysfunctional behaviours never being sufficiently established. Thus, the present/absent classificatory system does not accurately represent clinical reality (16) and frequently leads to misdiagnosis (17). Categorical personality disorders do not represent distinct diagnostic entities (18), as there is a problem with the diagnostic categories and the criteria within these categories (19).

Another significant criticism of the DSM diagnosis of personality disorder is that the DSM system places personality disorder on a separate diagnostic axis 2 than other mental disorders. The rationale for this was to prevent personality disorders from being overlooked due to the presence of more pronounced axis I psychiatric disorders although the ICD 10 classification retained personality disorders on axis I with other mental illnesses (4). Livesley et al (3) opined: "...Consistent with the Neo-Kraeplin position that has shaped much of the thinking about the DSM III (20), clinical syndromes were considered to be largely biological in origin, whereas personality disorders were believed to result from adverse psychosocial development experiences. This distinction was politically advantageous; the psychoanalytic movement was placated for the loss of neurosis by the placement of disorders believed to be amenable to psychoanalytic treatment on a separate axis...." Perhaps the most poignant criticism to be levelled at the ICD/DSM categorical system of personality disorder classification relates to the absence of treatment predictability and specificity for the diagnostic category. The absence of a system for measuring the severity of the condition also makes treatment planning and specificity difficult and unreliable.

\section{Proposed DSM-5 personality disorder classification}

The DSM-5 attempts to integrate a prototype-matching system and identification of personality traits. The essential features of the new DSM-5 classification of personality disorder are impairments in personality (self and interpersonal) functioning and the presence of pathological personality traits. Livesley (21) lamented that the new proposal totally reformulates the way personality disorders are classified so that there is virtually no continuity with the previous system. The new reformulation, he suggests, is a confusing mixture of innovation and a return to previous ways of representing diagnostic constructs that is inconsistent, incoherent, impractical and frequently incompatible with empirical facts. Particularly problematic is the replacement of criterion-based diagnosis with a prototype matching system that is based on cognitive heuristics that can lead to biased diagnoses and relies on implicit and intuitive rather than specifiable and observable, which reduces replicability. This implementation, Livesley suggests, will result in personality disorder being diagnosed in a fundamentally different way from all other disorders in psychiatry and medicine. Implementation of the proposal would have serious adverse consequences for patients, treatment, research, and administrative and legal applications, especially in the area of psychological injury and law and that the new system may be so confusing and time consuming that it might decrease diagnostic reliability and validity.

\section{Phenomenological classification}

The contradictions in current personality disorder diagnosis have left us with a classificatory system that imposed reified categories increasingly at variance with data generated and increasingly divorced from scientific inquiry. Phenomenological approaches share the aim of systematically considering and studying human experience and behaviour in a manner that does not start from prior theories and assumptions. Research and clinical problems with the current DSM/ICD classification systems might be alleviated by a return to a more descriptive psychopathology classification system based on the phenomenological method (17). The phenomenological approach focuses on the recording of the ex- 
perience in its entirety and does not set out to explain or quantify it. Phenomenology as defined by Jaspers in $1923 / 1963$ (24) is the subjective and objective experiences of human psychic life, which for psychopathologists is purely an empirical method of enquiry maintained solely by the fact of the patients' communications (24).

\section{The Jamaican experience}

The teaching of psychiatry was introduced in the medical curriculum at The University of the West Indies (UWI) in 1965 (23) while clinical psychology was established in the UWI in 2002 (24). The main focus of the curriculum was on psychoses and the development of community mental health services $(25,26)$. Initial focus on personality disorder was by the political scientists $(27,28)$ in the mid- $20^{\text {th }}$ century who paid more attention to aetiology and social manifestations. The work of English social psychologist Madeline Kerr for the West Indian Social Survey in Jamaica 1947-1949 provides an insight into the development of personality disorder in this country as stemming from the cultural tensions resulting from the conflicts between the African heritage of the majority population and the British values imposed during slavery. Political scientist Carl Stone buttresses Kerr's suggestion that these problems have existed in Jamaica for centuries and are responsible for the development of personality and institutional disorders that plague contemporary Jamaica, leading to "serious personality disorders in our culture" (28).

The psychiatric study of personality disorder in Jamaica emerged in the 1970s following exchange programmes of young psychiatrists between the Department of Psychiatry at the UWI and the Department of Psychiatry at the University of Edinburgh (29). Professor of psychiatry and psychotherapist in Edinburgh, Dr Henry Walton, a pioneer in the study of personality disorder, focussed attention on the classification of personality disorder based on a nosology of insight. Criticizing the DSM and ICD systems rating of severity as limited in logical basis and clinical application that was based on the diagnosis given to the patient rather than their level of functional impairment, Walton et al recommended improvement in description of psychiatric illness with an inclusion of personality deviations in the nosological classification (30) and proposed that the severity of this condition be formulated on a graded diagnostic rating of mild, moderate or severe using social disruption and insight as markers of severity (31).

In a pilot study of 34 patients who were diagnosed by the DSM-III as having a personality disorder, the phenomenological features of this clinical cohort were disaggregated and analysed statistically into three clinically observable clusters of (a) power management and authority phenomena, (b) dependency phenomena (psychological and physiological) and (c) psychosexual phenomena, which was called a clinical triad $(29,32)$. This was followed by a study of a cohort of 351 patients diagnosed with DSM personality disorder, matched with a cohort of patients for age, gender and social class, and the disaggregated phenomenology of both cohorts were analysed and compared. The study confirmed the presence of the clinical triad, which led to the proposal of a new Axis I classification for personality disorder, associated with problems of authority, power and conflict management, and impulse control, as a replacement for traditional DSM criteria (33). This Jamaican study proposed the term Shakatani as a possible name for the recommended Axis I condition, with the concept of Shakatani being derived from the Swahili words shaka ("problem") and tani ("power").

The UWI study of personality disorder evolved a 38item screening questionnaire - the Jamaica Personality Disorder Inventory (JPDI) - designed to elicit the clinical triad from a brief interview. The JPDI was successfully validated on a cohort of 200 patients at the University Hospital of the West Indies (UHWI), using the validating comparisons of the semistructured interviews of the DSM-IV-TR personality disorder classification and the International Personality Disorder Inventory (IPDE) as the gold standard inventory (34). Using this methodology, the prevalence rates of personality disorder in medical wards, psychiatric ward patients and substance abuse ward patients at UHWI were also established $(35,36)$. A four-stage stratified random sampling method was used to obtain a representative population sample consisting of 1506 Jamaicans to establish the prevalence of personality disorder in the Jamaican population using the JPDI as the diagnostic screening instrument, conducted by Market Research Services Limited (38), a reputable Jamaican market research organization.

\section{The diagnosis and prevalence of personality disorder in Jamaica}

The UWI findings have signposted this phenomenological approach to personality disorder as being viable for Jamaica, with the population prevalence study reporting that two-fifths $(41.4 \%)$ of the Jamaican stratified sample studied was eligible for a diagnosis of personality disorder (37). Epidemiological studies and national population surveys done in the USA, Canada, New Zealand and Europe have indicated prevalence rates of personality disorder between $13-15 \%$ (39-41). The Jamaican population prevalence rate compares with a rate of $28 \%$ for the diagnosis of personality disorder in non-psychiatric patients of medical wards of the UHWI (35) and $57 \%$ in patients in the psychiatric wards of that hospital (36). The differences between the international rates and the Jamaican rate may be explained by at least one of two factors. First, the Jamaican rate was obtained from a screening instrument and not from personal interviews, and culled responses that equate results for mild, moderate and severe personality disorders, whereas the international rates relate only to severe pathology culled from interview-driven methods. Second, it is possible that the cut scores used to calculate the Jamaican rates may have been calibrated at too high a figure. However, as a statistical $t$-test was employed 
to determine the cut score on the JPDI, which was correlated with reference to the sensitivity, specificity and predictive values of the psychiatrist clinical DSM-IV-TR interview diagnosis of personality disorder (37), it is suggested that the cut score used was accurate and that the $41.4 \%$ finding expresses a reliable population range from mild to severe.

When the psychological correlates of dependency, power management, and psychosexual abnormalities from the population responses to the specific questions of the JPDI were examined separately, the responses ranged from $23 \%$ for dependency phenomena (42), 31\% for abnormal power management phenomena (43), and $20 \%$ for psychosexual phenomena (44). These studies indicate that the $23-31 \%$ of the Jamaican people who responded positively to the JPDI interview rated themselves as having an abnormal response to the questions being asked. The conclusion that there is a personality disorder psychopathology in a broad one-third swathe of the Jamaican population is therefore likely.

Despite advances in economic, political and social development within the society, crime, structural and interpersonal violence continue to increase in Jamaica, with a homicide rate of 53/100 000 in 2005 being the third highest in the world after El Salvador and Iraq (45). Primary data from a psychosociological study of condemned Jamaican murderers provides us with the finding that $66 \%$ of the cohort of 35 men convicted for murder in Jamaica in 1974 had a DSM-IV-TR diagnosis of antisocial personality disorder (46). The Jamaican society stands indicted as a major repository of personality disorder and insane homicidal violence in this country, and therefore represents a major public health problem in contemporary Jamaica. The historiographic analysis of the short story writings of a Jamaican novelist (47) also mirrors in contemporary literature the clinical syndrome of personality disorder revealed from contemporaneous Jamaican medical research.

\section{The psychotherapeutic treatment of personality disorder} A significant criticism levelled at the ICD/DSM categorical system of personality disorder classification relates to the absence of treatment predictability. The classificatory nosology emerging from the UWI research (32) forecasts a psychotherapeutic direction requiring dialectic psychological and political insight into the effect of trauma, failures of attachment, authority and impulse control in personal development as the main therapeutic direction implicated for treatment, with a personalized behaviour modification strategy engineered to negate and to work through these developmental scotoma. A study outlining the novel psychohistoriographic brief psychotherapy (PBP) developed purposely in Jamaica to meet these psychopathological conundrums confirms this forecast (48), by presenting positive medium term outcome responses of a cohort of 100 patients in Jamaica, diagnosed with personality disorder and treated with PBP. A randomized control trial is required to confirm the efficacy of this therapeutic modality.

\section{Social and media responses to personality disorder research in Jamaica}

The newspaper publication of the population prevalence of personality disorder (49) stunned the Jamaican public and resulted in a veritable avalanche of media and social media responses in Jamaica. The newspaper also reported that this UWI Jamaican research correspondingly indicated that many Jamaican leaders suffer from personality disorder and mental illness (50). Harrowing and seemingly never-ending reports of homicides, beheadings, murder-suicides, domestic violence and heinous social transgression in the print and broadcast media coincided with the popularization of this personality disorder research. Media popularization (social scholarship) of this research led to a series of public scholarship engagements with the Jamaican media landscape that has resonated with the psychosocial developmental events in this period of time (51). Jamaican people seemed to be acquiring insight into the deep scotoma and blind spots of its society and waking up to the causal inter-connections of individual psychopathology, social structural deficiencies and the seemingly hopeless endemic problems of this postcolonial country. The Sunday Gleaner of July 17, 2011, reported that more than 1500 children and teenagers had been killed in Jamaica since 2001 (52). The police and military 'State of Emergency' incursion in the West Kingston community of Tivoli Gardens which led to the reported killing of over 70 persons, and the United States extradition and conviction of Christopher "Dudus" Coke for drug-related and violent crimes at home and abroad, seemed to have been the tipping point of insight for the Jamaican people. Social commentator Martin Henry makes the point: “...It appears to me, without the benefit of a scientific study, that political leaders who can build garrisons and use political violence as a tool for electoral victory and then display all the innocence and gentleness of a lamb would have Jekyll and Hyde personalities..." (53).

\section{CONCLUSIONS}

Pathological conflict is endemic in almost every aspect of Jamaican society with such behaviour reflecting a significant prevalence of personality disorders in contemporary Jamaica. It is concluded that Jamaican psychiatry needs redefinition of the diagnosis and classification of personality disorder and the need to create novel therapies that can engineer and catalyse social transformation and change of this mental pathology.

\section{REFERENCES}

1. Manley M. Jamaica: struggle in the periphery. London: Third World Media/Writers and Readers Publishing Cooperative; 1982.

2. American Psychiatric Association. Diagnostic and statistical manual of mental disorders $4^{\text {th }}$ edition, text revision (DSM-IV-TR). Virginia, USA: American Psychiatric Association Press; 2000.

3. Livesley WJ, Schroeder ML, Jackson DN, Jang KL. Categorical distinctions in the study of personality disorders: implications for classification. J Abnorm Psychol 1994; 103: 6-17. 
4. Tyrer P, Coombs N, Ibrahimi F, Mathilakath A, Bajaj P, Ranger M et al Critical developments in the assessment of personality disorder. Br J Psychiatry 2007; 190 (Suppl 49): s51-s59.

5. Pinel P. Traite medico-philosophique sur l'alienation mentale. $2^{\text {nd }}$ ed. Paris: Chez J Ant Brosson; 1809: 156.

6. Connolly J. An inquiry concerning the indications of insanity. London: John Taylor; 1830

7. Prichard JC. treatise on insanity. London: Sherwood, Gilbert and Piper; 1835: 14.

8. Koch JLA. The psychopathic inferiorities. Ravensburg, Germany: Dorn; 1891.

9. Schneider K. Die psychopathischen personlichkeiten. Springer; 1923.

10. Henderson DK. Psychopathic states. New York: Norton; 1939: 178.

11. World Health Organization. International Classification of Diseases (ICD). Geneva: World Health Organization; 1992.

12. Hathaway SR, McKinley JC. A multiphasic personality schedule (Minnesota): construction of the schedule. J Psychol 1940; 10: 249-54.

13. Reich J, Thompson WD. DSM III personality disorder clusters in three populations. Br J Psychiatry 1987; 150: 471-5.

14. Jones E, Zoppel CL. Personality differences among blacks in Jamaica and the United States. J Cross-Cult Psychol 1979; 10: 435-56.

15. Widiger TA, Sanderson C, Warner L. The MMPI, prototypal typology, and borderline personality disorder. J Pers Assess 1986; 50: 540-53.

16. Williams JB, Spitzer RL. The issue of sex bias in DSM-III: a critique of "A Woman's View of DSM-III" by Marcie Kaplan. American Psychologist 1983; 38: 793-8.

17. Mullen P. A modest proposal for another phenomenological approach to psychopathology. Schizophr Bull 2007; 33: 113-21.

18. Trull TJ, Tragesser SL, Solhan M, Schwartz-Mette R. Dimensional models of personality disorder: Diagnostic and Statistical Manual of Mental Disorders fifth edition and beyond. Curr Op Psychiatry 2007; 20: $52-6$.

19. Schedler J, Weston D. Refining personality disorder diagnosis: integrating science and practice. Am J Psychiatry 2004; 161: 1350-65.

20. Blashfield RK: The classification of psychopathology. New York: Plenum Press; 1984.

21. Livesley WJ. Confusion and incoherence in the classification of personality disorder: commentary on the preliminary proposals for DSM-5. Psychol Inter J Law 2010; 3: 304-13.

22. Jaspers K. Allgemeine psychopathologie. Berlin, Germany: Springer; 1913.

23. Beaubrun MH. Caribbean psychiatry yesterday today and tomorrow. History of Psychiatry 1992; 3: 371-82.

24. Hickling F, Matthies B. The establishment of a clinical psychology postgraduate program at the University of the West Indies, Mona. Caribbean J Education 2004; 25: 25-36.

25. Hickling FW, Gibson RC. Decolonization of psychiatric public policy in Jamaica. West Indian Med J 2012; 61: 435-9.

26. Hickling FW, Hutchinson G. Caribbean contributions to contemporary psychiatric psychopathology. West Indian Med J 2012; 61: 440-4.

27. Kerr M. Personality and conflict in Jamaica. London: Collins/ Sangster's; 1963

28. Stone C. The anatomy of aggression. The Daily Gleaner. 1992 Oct 21.

29. Hickling FW, Martin J, Harrisingh-Dewar A. Redefining personality disorder in Jamaica. In: Hickling FW, Matthies BK, Morgan K, Gibson $\mathrm{RC}$, eds. Perspectives in Caribbean psychology. Kingston: CARIMENSA Press, The University of the West Indies; 2008.

30. Walton HJ, Foulds GA, Littman SK, Presly AS. Abnormal personality. Br J Psychiatry 1970; 116: 497-510.
31. Walton HJ, Presly AS. Use of a categorical system in the diagnosis of abnormal personality. Br J Psychiatry 1973; 122: 259-68.

32. Hickling FW, Walcott G, Paisley V. Shakatani: the phenomenology of personality disorder in Jamaican patients. West Indian Med J 2013; 62: 397-404.

33. Hickling FW, Paisley V. Redefining personality disorder: a Jamaican perspective. J Pan Am Public Health 2011; 30: 255-61.

34. Hickling FW, Matrin J, Walcott G, Paisley V, Hutchinson N, Clarke TR et al. The creation and validation of the Jamaica Personality Disorder Inventory. West Indian Med J 2013; 62: 389-96.

35. Martin J, Walcott G, Clarke TR, Barton EN, Hickling FW. The prevalence of personality disorder in a general medical hospital population in Jamaica. West Indian Med J 2013; 62: 463-7.

36. Walcott G, Martin J, Hickling FW. The prevalence of personality disorder in a psychiatric and substance abuse population in Jamaica. West Indian Med J 2013; 62: 458-62.

37. Hickling FW, Walcott G. Prevalence and correlates of personality disorder in the Jamaican population. West Indian Med J 2013; 62: $443-7$.

38. Market Research Services Limited (MRSL) [homepage on the Internet]. Kingston, Jamaica: Market Research Services Limited [cited 2011 Aug 31]. Available from: http://www.mrsl.com.jm/

39. Weissman MM. The epidemiology of personality disorders: a 1990 update. J Pers Disord 1993; 7 (Suppl 1): 44-62.

40. Torgersen S, Kringlen E, Cramer V. The prevalence of personality disorders in a community sample. Arch Gen Psychiatry 2001; 58: $590-6$.

41. Grant BF, Hasin DS, Stinson FS, Dawson DA, Chou SP, Ruan WJ et al. Prevalence, correlates and disability of personality disorders in the United States: results from the national epidemiological survey on alcohol and related conditions. J Clin Psychiatry 2004; 65: 948-58.

42. Walcott G, Hickling FW. The psychological correlates of dependency in the Jamaican population. West Indian Med J 2013; 62: 411-16.

43. Walcott G, Hickling FW. Correlates of conflict, power and authority management, aggression and impulse control in the Jamaican population. West Indian Med J 2013; 62: 405-10.

44. Walcott G, Hickling FW. Correlates of psychosexual issues in the Jamaican population. West Indian Med J 2013; 62: 417-22.

45. Krause K, Muggah R, Gilgen E. Global burden of armed violence. Cambridge: Cambridge University Press; 2011.

46. Hickling FW, Walcott G. Personality disorder in convicted Jamaican murderers. West Indian Med J 2013; 62: 453-7.

47. Hickling FW. Historiographic analysis of the Jamaican 'Shakatani' scotoma from the short stories of Erna Brodber. West Indian Med J 2013; 62: 475-80.

48. Hickling FW. The treatment of personality disorder in Jamaica with psychohistoriographic brief psychotherapy. West Indian Med J 2013; 62: 431-4.

49. Reid T. Mental alert. Jamaica Gleaner. 2011 Jan 16: News.

50. Reid T. Disorder in high office. Jamaica Gleaner. 2011 Jan 16: News.

51. Hickling FW, Robertson-Hickling HA. Media representation of personality disorder in Jamaica - public scholarship as a catalyst of health promotion. West Indian Med J 2013; 62: 448-52.

52. Reid T. Murderous! More than 1,500 children and teenagers killed since 2001. Jamaica Gleaner. 2011 Jul 17: News.

53. Henry M. This madness has to stop. As family values collapse and social bonds unravel, Jamaicans are going bonkers. Jamaica Gleaner. 2012 Sep 23: In Focus. Available from: http://jamaica-gleaner.com/ gleaner/20120923/focus/focus1.html 